\title{
MANAJEMEN KEUANGAN DAN PACKING UNTUK USAHA KECIL MENENGAH (UKM) DI KECAMATAN TANDES SURABAYA
}

\author{
Muchammad Nurif, Windiani, Sukriyah Kustansi, Syukrianti Muchtar
}

\begin{abstract}
Abstrak
UKM merupakan salah satu motor penggerak perekonomian rakyat, terutama rakyat menengah ke bawah. Meskipun secara agregat kontribusi terhadap pendapatan daerah adalah kecil dibandingkan dengan pengusaha besar, namun UKM banyak menolong masyarakat banyak pada waktu perekonomian Indonesia terpuruk.

Masalah utama dari sulit berkembangnya UKM adalah karena daya kreatif dan inovatif yang relatif rendah. Hal ini terutama didukung dengan latar belakang pendidikan mereka yang rendah, selain itu para pengusaha ini tidak mudah mendapatkan modal untuk mengembangkan usahanya karena kelemahan dalam bidang administrasi dan pembukuan keuangan mereka. Kelemahan lain adalah pada konsep produk, terutama kemasan (packing), yang sering kali melupakan faktor kebersihan dan kesehatan.

Untuk itu, pelatihan ini diadakan untuk memberi ketrampilan bagi para UKM di Kecamatan Tandes khususnya agar mereka terbiasa dan mahir dalam mengelolah keuangan secara modern. Setidaknya mereka tidak kesulitan jika mengajukan pinjaman ke bank untuk mengembangkan usahanya. Pelatihan ini juga untuk membekali pengetahuan para UKM tentang teknik dan model kemasan yang menarik dan sesuai dengan produk-produk mereka.
\end{abstract}

Kata Kunci: Laporan keuangan, Neraca, Laporan Laba Rugi, Packing

Globalisasi ekonomi dan era informasi mendorong industri berbagai sumber daya yang ada untuk mengembangkan industri dan usahanya. Namun hal ini kurang berlaku di bagi para pengusaha kecil atau UKM di Indonesia. Globalisasi ekonomi bisa membuat mereka semakin keluar dari bisnis karena tidak mampu bersaing. Mereka tidak bisa bersaing dalam hal kreatifitas, inovasi, modal maupun teknologi.

Disisi lain, UKM banyak menyumbang pendapatan dan lapangan pekerjaan, bagi masyarakat kecil. Meskipun pemerintah banyak sekali mengeluarkan kebijakan baik berupa peraturan tentang permodalan dan perlindungan, namun masih ada kebocoran disana sini yang membuat tidak semua UKM dapat menikmati skim yang ditawarkan oleh pemerintah. Skim 
pelatihan, permodalan dan pameran hanya menyetuh sedikit UKM di Indonesia yang jumlahnya ribuan.

Salah satu kumpulan UKM yang kurang tersentuh oleh skim maupun kebijakan pemerintah adalah komunitas UKM di Kecamatan Tandes. Kebetulan pengelola UKM ini juga mempunyai komunitas petani jamur yang bernama Kelompok Tani Jempolan. Komunitas UKM di Kecamatan Tandes relatif cukup progresif usaha untuk mengembangkan diri. Hal ini didukung dengan semakin maju dan padatnya wilayah Surabaya Barat, baik dari segi populasi maupun dunia bisnisnya. Perlu sekali membekali para UKM ini agar bisa eksis di tengah pengusaha-pengusaha menengah-besar yang mulai banyak menjamur dan berkembang di Surabaya Barat.

Berdasarkan hasil diskusi dengan ketua kelompok tani 'jempolan', peserta pelatihan ada 25 orang pemilik UKM di wilayah kecamatan Tandes Surabaya Barat. Daftar peserta dan jenis usahanya bisa dilihat dilampiran.

Berdasarkan uraian di atas beberapa permasalahan yang dihadapi oleh para pengusaha UKM di Kecamatan Tandes adalah:

a. Kurangnya kemampuan/referensi yang dimiliki para pengusaha dalam pengelolan keuangan.

b. Kurangnya kemampuan/referensi yang dimiliki para pengusaha dalam pembuatan laporan keuangan yang sesuai dengan standar bank/lembaga keuangan.

c. Kurangnya pengetahuan dan pemahaman yang dimiliki para pengusaha atas arti penting kemasan produk

Dari perumusan masalah diatas dapat ditentukan tujuan dari penulisan ini adalah:

a. Untuk meningkatkan kemampuan/referensi yang dimiliki para pengusaha UKM dalam pengelolan keuangan.

b. Untuk meningkatkan kemampuan/referensi yang dimiliki para pengusaha UKM dalam penyusunan laporan keuangan sesuai standar bank/lembaga keuangan. 
c. Untuk meningkatkan pengetahuan dan pemaham para pengusaha UKM dalam teknik dan model pengemasan.

Selain itu pelatihan ini diharapkan akan membantu dan mempermudah para UKM di Kecamatan Tandes untuk memperoleh pinjaman modal yang diperlukan bagi pengembangan usahanya.

\section{Tinjauan Pustaka}

Krisis moneter yang pernah melanda Indonesia ditahun 1996 lalu mengakibatkan terpuruknya kondisi ekonomi kita yang masih terasa dampaknya hingga saat ini. Meskipun secara perlahan bangsa kita terus melakukan pemulihan ekonomi, namun hal tersebut tidak serta merta mampu mengembalikan kondisi ekonomi kita seperti sebelum krisis tersebut terjadi. Belum lagi efek pasar global yang belakangan ini "memaksa" kita untuk membuka pintu terhadap masuknya semua produk-produk yang berasal dari negara tetangga, hal ini membuat tingkat persaingan antara produk luar dengan produk lokal semakin ketat. Dari sisi internal sendiri, masih banyaknya praktek-praktek penyelundupan produk-produk dari luar oleh pengusaha-pengusaha nakal serta masih kurangnya apresiasi masyarakat terhadap produk-produk lokal yang ada (import minded) membuat semakin beratnya beban yang dipikul untuk mengembalikan kondisi perekonomian Indonesia.

Sebenarnya pemerintah sebagai pemegang kebijakan memiliki fungsi vital dalam mengatasi permasalahan ini, pemberian sanksi yang tegas kepada pengusahapengusaha nakal dan memberi fasilitas bagi para pengusaha lokal tentunya akan membuat pemulihan kondisi ekonomi Indonesia semakin cepat. Tentunya dengan catatan semua kebijakan yang diambil tersebut harus dilaksanakan secara fokus dan berkelanjutan karena dampak dari penerapan sebuah kebijakan baru akan terlihat beberapa waktu kedepan.

Menjadikan Usaha Kecil dan Menengah (UKM) sebagai basis ekonomi bangsa dapat menjadi alternatif pilihan guna mengangkat perekonomian kita dari keterpurukan. Disaat banyak pengusaha-pengusaha besar yang kolaps akibat krisis moneter yang terjadi, justru para pelaku Usaha Kecil dan Menengah (UKM) yang banyak tersebar di seluruh kepulauan Indonesia masih tetap mampu bertahan dari 
terjangan krisis yang melanda pada saat itu. Jumlah sumber daya manusia (SDM) yang dibarengi dengan jumlah sumber daya alam (SDA) yang melimpah menjadikan negara kita memiliki potensi yang luar biasa untuk mengembangkan ekonomi berbasis Industri Kecil Menengah (IKM).

Terkadang birokrasi pemerintahan yang berbelit-belit malah akan menambah daftar faktor-faktor penyebab sulitnya Usaha Kecil dan Menengah (UKM) berkembang di Indonesia. Oleh karena itu, banyak pelaku-pelaku usaha yang saat ini telah berhasil mengembangkan usahanya tanpa sama sekali mendapat bantuan dari pemerintah baik itu bantuan berupa modal usaha ataupun pelatihan kewirausahaan. Dari pada pusing-pusing memikirkan birokrasi pemerintahan yang rumit hanya demi mendapatkan bantuan yang tidak seberapa, lebih baik mencari cara alternatif lain yang lebih singkat dan cepat. Usaha lebih cepat dijalankan, keuntungan juga lebih cepat bisa diperoleh.

Intinya semua kembali lagi kepada pemerintah, langkah-langkah apa saja yang akan diambil untuk mengatasi keterpurukan ekonomi ini. Jika sudah tahu bahwa Usaha Kecil dan Menengah (UKM) memiliki fungsi dan peranan yang positif, bukan saja akses yang sebesar-besarnya kepada mereka. Toh, keadaan di lapangan yang menggambarkan sendiri bagaimana UKM bisa bertahan dari semua terpaan krisis yang melanda. $(\boldsymbol{D W})$

\section{Definisi UKM}

Menurut Hubeis (2009), UKM didefinisikan dengan berbagai cara yang berbeda tergantung pada negara dan aspek-aspek lainnya. Oleh karena itu, perlu dilakukan tinjauan khusus terhadap definisi-definisi tersebut agar diperoleh pengertian yang sesuai tentang UKM, yaitu menganut ukuran kuantitatif yang sesuai dengan kemajuan ekonomi.

Berbagai definisi mengenai UKM dalam Hubeis (2009) yaitu:

1. Di Indonesia, terdapat berbagai definisi yang berbeda mengenai UKM berdasarkan kepentingan lembaga yang memberi definisi.

a. Badan Pusat Statistik (BPS): UKM adalah perusahaan atau industri dengan pekerja antara 5-19 orang. 
b. Bank Indonesia (BI): UKM adalah perusahaan atau industri dengan karakteristik berupa: (a) modalnya kurang dari Rp. 20 juta; (b) untuk satu putaran dari usahanya hanya membutuhkan dana Rp 5 juta; (c) memiliki aset maksimum Rp 600 juta di luar tanah dan bangunan; dan (d) omzet tahunan $\leq$ Rp 1 miliar.

c. Departemen (Sekarang Kantor Menteri Negara) Koperasi dan Usaha Kecil Menengah (UU No. 9 Tahun 1995): UKM adalah kegiatan ekonomi rakyat berskala kecil dan bersifat tradisional, dengan kekayaan bersih RP 50 juta Rp 200 Juta (tidak termasuk tanah dan bangunan tempat usaha) dan omzet tahunan $\leq$ Rp 1 miliar; dalam UU UMKM/2008 dengan kekayaan bersih Rp 50 juta - Rp 500 juta dan penjualan bersih tahunan Rp 300 juta - Rp 2,5 miliar.

d. Keppres No. 16/1994: UKM adalah perusahaan yang memiliki kekayaan bersih maksimal Rp 400 juta.

e. Departemen Perindustrian dan Perdagangan:

2. Perusahaan memiliki aset maksimal Rp 600 juta di luar tanah dan bangunan (Departemen Perindustrian sebelum digabung).

3. Perusahaan memiliki modal kerja di bawah $\mathrm{Rp} 25$ juta (Departemen Perdagangan sebelum digabung).

4. Departemen Keuangan: UKM adalah perusahaan yang memiliki omset maksimal Rp 600 juta per tahun dan atau aset maksimum Rp 600 juta di luar tanah dan bangunan.

5. Departemen Kesehatan: perusahaan yang memiliki penandaan standar mutu berupa Sertifikat Penyuluhan (SP), Merk Dalam Negeri (MD) dan Merk Luar Negeri (ML).

6. Di negara lain atau tingkat dunia, terdapat berbagai definisi yang berbeda mengenai UKM yang sesuai menurut karakteristik masing-masing negara, yaitu :

a. World Bank: UKM adalah usaha dengan jumlah tenaga kerja \pm 30 orang, pendapatan per tahun US\$ 3 juta dan jumlah aset tidak melebihi US\$ 3 juta.

b. Di Amerika: UKM adalah industri yang tidak dominan di sektornya dan mempunyai pekerja kurang dari 500 orang. 
c. Di Eropa: UKM adalah usaha dengan jumlah tenaga kerja 10-40 orang dan pendapatan per tahun 1-2 juta Euro, atau jika kurang dari 10 orang, dikategorikan usaha rumah tangga.

d. Di Jepang: UKM adalah industri yang bergerak di bidang manufakturing dan retail/ service dengan jumlah tenaga kerja 54-300 orang dan modal $¥ 50$ juta -300 juta.

e. Dik Korea Selatan: UKM adalah usaha dengan jumlah tenaga kerja $\leq 300$ orang dan aset $\leq$ US\$ 60 juta.

f. Di beberapa Asia Tenggara: UKM adalah usaha dengan jumlah tenaga kerja 10-15 orang (Thailand), atau 5-10 orang (Malaysia), atau 10-99 orang (Singapura), dengan modal \pm US\$ 6 juta.

\section{Stategi, Rencana Kegiatan dan Keberlanjutan}

Strategi penentuan peserta yang dilaksanakan dalam pelatihan keuangan dan kemasan ini adalah diutamakan peserta pengusaha UKM yang usahanya sudah lama dan prospek untuk dikembangkan bagus. Sehingga kebutuhan mereka akan permodalan cukup penting dan signifakan.

Kegiatan ini akan dilaksanakan dalam waktu 2 hari. Untuk penentuan harinya akan didiskusikan dengan ketua kelompok tani dan peserta pelatihan itu sendiri. Teknik yang digunakan dalam pemberian materi pelatihan adalah sebagai berikut: (1) Small Group Discussion yaitu : Mendiskusi masalah yang dihadapi peserta terkait dengan pengelolaan keuangan, pengajuan pinjaman ke bank/investor/lembaga keuangan non bank. Dan Mendiskusikan masalah kemasan produk yang ada. (2) Penugasan Self Directed Learning, yaitu: Mempelajari pengeluaran dan pemasukan administrasi keuangan masing-masing UKM; Menyusun draft laporan keuangan berdasarkan usaha masing-masing UKM; Mencari kelemahan kemasan dari masing-masing UKM. (3) Discovery Learning, yaitu: Mengevalusai draft laporan keuangan; Menyusun kembali laporan keuangan sesuai dengaan standar akuntansi dan standar laporan keuangan bank, Membenahi kemasan sesuai dengan teknik dan teknologi dalam pembuatan kemasan yang sesuai dengan usaha masing-masing UKM. (4) Simulasi yaitu : Presentasi laporan 
keuangan, khususnya neraca dan laporan keuangan, serta jenis kemasan yang cocok dengan produk UKM.

\section{Hasil dan Pembahasan}

Langkah awal yang dilakukan adalah melakukan survey tempat yaitu di Gedung Primagama Jl. Raya Darmo Indah Timur Blok EU No. 1 Surabaya sebagai tempat pelatihan. Dari hasil survey awal ini didapatkan bahwa lokasi para Usaha Kecil Menengah (UKM) saling berdekatan disekitar Kecamatan Tandes. Jumlah UKM yang tersebar di Kecamatan Tandes kurang lebih 250 UKM. Namun karena terbatasnya anggaran dana yang tersedia, hanya dipilih 25 UKM. Yang mewakili datang untuk ikut pelatihan adalah pemilik UKM sendiri. Mereka ingin langsung mendapatkan ilmu dan pengetahuan tentang pembukuan dan packing.

Hari Pertama acara dimulai tepat pukul 09.00 WIB, diawali dengan pembukaan oleh ketua tim pengabdi dan sambutan oleh koordinator UKM Ibu Ririn Ardianty. Acara dilanjutkan dengan pemberian materi ke-1 pelatihan bertema "Membangun Bangsa dengan Wirausaha" (pentingnya berwirausaha) yang disampaikan oleh Muchammad Nurif, SE. MT. Peserta mengikuti pelatihan dengan sangat antusias, hal ini terlihat ketika pada sesi tanya jawab mereka banyak mengajukan pertanyaan berkaitan dengan pentingnya berwirausaha.

Materi ke-2 dilanjutkan dengan "Kredit Usaha Mikro, Kecil dan Menengah" yang disampaikan oleh Bpk Muhammad Irmansyah dari Bank Mandiri Divisi UKM. Pada materi ini peserta tidak kala antusias dikarenakan yang memberikan materi adalah dari pihak Bank Mandiri yang sewaktu-waktu dapat memberikan pengucuran kredit UKM. Pertanyaan dari peserta mengalir begitu banyak dan variatif. Sebelum dilanjutkan pada materi ke-3 peserta diperkenankan untuk ISHOMA, kemudian dilanjutkan kembali pukul 13.30 WIB. Materi ke-3 ini disampaikan oleh Endang Sudarsih, SE. M.Si, MT dengan materi Pembukuan Sederhana UKM. Di akhir sesi dibuka diskusi dan simulasi pembuatan laporan keuangan oleh peserta pelatihan.

Selama pelatihan hari pertama ini, peserta mendapatkan fasilitas dari panitia berupa buku kas, pencil, penghapus, snack pagi dan sore dan tidak lupa makan siang. Secara keseluruhan pelatihan hari pertama ini berjalan dengan lancar. 
Hari Kedua acara dimulai pukul 09.00 WIB, ada sedikit kendala dimana peserta yang hadir pada kegiatan dimulai hanya 9 orang peserta. Namun seiring berjalannya waktu peserta datang satu per satu, hingga hari kedua inipun peserta masih antusias hadir mengikuti pelatihan.

Berbeda dengan hari sebelumnya, di hari kedua materi ke-4 disampaikan oleh Ibu Syukrianti Mukhtar dengan materi Packing. Peserta diberikan pengetahuan yang sangat luar biasa oleh pemateri, karena pemateri mempunyai pengalaman dan jam terbang yang cukup tinggi dalam hal packing. Materi ke-4 berakhir sampai jam 10.30 WIB. Dan dilanjutkan dengan materi ke-5 dengan materi Workshop Packing yang disampaikan oleh mahasiswa Jurusan Teknik Industri ITS yaitu Satrio Dewantoro dan Ahmad Fraidee P.

Kegiatan ditutup dengan sharing terbuka oleh semua pemateri. Pelaksanaan disain atau metode pelatihan yang digunakan adalah:

\section{- Small Group Discussion}

Bagaimana menilai dan mengembangkan potensi enterpreneurship seseorang. Peserta dibagi dalam beberapa kelompok kecil selanjutnya dipandu oleh seorang instruktur untuk diskusi memecahkan permasalahan yang dihadapi oleh sekolah masing-masing.

- Simulasi

Untuk menggugah otak bawah sadar akan pentingnya mindset keuangan, spirit berprestasi, pembelajaran, kemandirian, perencanaan, kreativitas, dan berani mengambil resiko.

Tahapan proses yang telah dilaksanakan, pertama kita membuat dan mengirimkan undangan ke koordinator UKM untuk menentukan peserta yang akan diundang untuk mengikuti pelatihan. Undangan dikirim jauh hari sebelum pelatihan ini dilaksanakan. Karena pada kenyataannya pelatih sangat dekat dengan lokasi UKM dan mengetahui kebutuhan UKM akan pentingnya pelatihan ini.

Pelatihan dilaksanakan selama dua hari pada tanggal 25 dan 26 Mei 2013 di gedung Primagama J1. Raya Darmo Indat Timur Blok EU No 1 Kecamatan Tandes Surabaya. Peserta yang diuandang dalam pelatihan 25 pemilik UKM. Berbagai jenis usaha yang mereka lakukan antara lain: kelompok makanan dan kue yang terdiri dari 
Kue kering, Wader krispy, Olahan Jamur Tiram, Olahan Ikan, Bakpia, Bronis/Frozen Bronis, Bronis Waluh. Kelompok minuman yang terdiri dari: Minuman Instan, Jahe Instan, Sinom. Kelompok Industri Kreatif yang terdiri dari: Fashion, Sulam Pita, Manik-manik, Rajutan, Batik Celup, Aksesories, Handycraft Enceng Gondok, Ikat Jumput Batik dan Toko Kelontongan.

Dalam pelaksanaannya, pelatihan ini dapat dibilang sukses, peserta sangat antusias mengikuti kegiatan ini hingga selesai. Pertanyaan dari peserta sering kali muncul di tengah para pemateri memberikan materi pelatihan.

\section{Feed Back Pelatihan}

\begin{tabular}{|c|c|c|c|c|}
\hline & $\begin{array}{c}\text { Tidak } \\
\text { Memuaskan }\end{array}$ & $\begin{array}{c}\text { Kurang } \\
\text { Memuaskan }\end{array}$ & Memuaskan & $\begin{array}{c}\text { Sangat } \\
\text { Memuaskan }\end{array}$ \\
\hline Materi & & & & \\
\hline$\bullet \quad$ Materi ke-1 & & & & $\mathrm{V}$ \\
\hline$\bullet \quad$ Materi ke-2 & & & $\mathrm{V}$ & \\
\hline$\bullet \quad$ Materi ke-3 & & & $\mathrm{V}$ & \\
\hline$\bullet \quad$ Materi ke-4 & & & $\mathrm{V}$ & \\
\hline$\bullet \quad$ Materi ke-5 & & & $\mathrm{V}$ & \\
\hline Ruang / tempat & & & $\mathrm{V}$ & \\
\hline Pembicara / Pemateri & & & & $\mathrm{V}$ \\
\hline Konsumsi & & & & \\
\hline
\end{tabular}

\section{Materi}

Dari 37 peserta pelatihan, 25 orang menyatakan bahwa materi dalam pelatihan ini sangat memuaskan dan perlu ada pelatihan seperti ini lagi karena sangat bermanfaat. 12 orang peserta menyatakan bahwa materi dalam pelatihan ini memuaskan dan bila perlu waktu diperpanjang lagi tidak hanya 2 (dua) hari.

Kalau perlu diselingi dengan film-film yang menarik, contoh kasus, game dan out bound Mereka berharap agar pihak Perguruan Tinggi juga sesekali turun ke bawah melihat secara langsung kondisi UKM di lapangan.

\section{Ruang/Tempat}

Sebagian besar peserta menyatakan bahwa tempat atau ruang memuaskan, meskipun ruangan tidak ber AC namun cukup memadai.

\section{Pembicara/Pemateri}


Pembicaranya menarik dan sangat memuaskan dalam menyampaikan materi, meskipun waktu untuk diskusi sangat singkat. Ada peserta yang menyatakan pelatihan seperti ini bisa diadakan 2 kali setahun. Peserta yang diundang bisa lebih banyak lagi. Alasannya masih banyak pelaku UKM yang tidak mengerti pembukuan dengan benar dan packing yang baik dan benar. Mereka masih membukukan keuangan secara amburadul/semrawut, sehingga antara keuangan usaha masih campur dengan keuangan keluarga. Packingnya juga masih sangat tradisional/sederhana sesuai dengan kemampuan mereka.

\section{Daftar Pustaka}

Arman Hakim Nasution, 2006 Creative Thinking, Andi Publisher, Yogyakarta

Brandt, Steven, 1995, Entreprenuership, Effhar Dahara Prize, Jakarta,

Buchori Alma, 1999, Kewirausahaan, Panduan Perkuliaan, Penerbit Alfabeta, Bandung,

Everret E.Adam and Ronald J.Ebet, 1992, Production and Operation Management, Englewood Clifft, New Jersey,

Husein Umar, 2001, Manajemen Resiko Bisnis, Gramedia Pustaka Utama, Jakarta http/www,scrid.com/doc/8969878/model Pembelajaran Efektif

Indriyo Gitosudarmo, 2001, Pengantar Bisnis, Edisi 2, BPFE, Yogyakarta,

Masykur Wiratmo, 1996, Pengantar Kewirausahaan; Kerangka Dasar Memasuki Dunia Bisnis, BPFE-Yogyakarta, Yogyakarta,

Sherwood, 2006, Innovation and Creativity, Elex Media, Bandung

Tim Entrepreneurship ITS, 2009, Entrepreneurship, ITSPress, Surabaya,

Yoseph Murphi, 2002, Membangkitkan Kekuatan Bawah Sadar,Pioner Jaya, Jakarta 